\title{
Determination of presence of Tritrichomonas foetus in uterine lavages from cows with reproductive problems
}

\author{
Determinação da presença de Tritrichomonas foetus em lavados uterinos de vacas com problemas reprodutivos
}

\author{
Lady Carolina González-Carmona ${ }^{1}$; Milena Jineth Sánchez-Ladino; Rubiela Castañeda-Salazar ${ }^{1 *}$; \\ Adriana del Pilar Pulido-Villamarín'; Humberto Guáqueta-Munar²; \\ Moisés Aranda-Silva ${ }^{3}$; Milton Januario Rueda-Varón ${ }^{3}$
}

\begin{abstract}
${ }^{1}$ Unidad de Investigaciones Agropecuarias - UNIDIA, Departamento de Microbiología, Facultad de Ciencias, Pontificia Universidad Javeriana, Bogotá, Colombia

${ }^{2}$ Departamento de Salud Animal, Facultad de Medicina Veterinaria y de Zootecnia, Universidad Nacional de Colombia, Bogotá, Colombia

${ }^{3}$ Departamento de Matemáticas, Facultad de Ciencias, Pontificia Universidad Javeriana, Bogotá, Colombia
\end{abstract}

Received July 27, 2011

Accepted November 16, 2011

\begin{abstract}
The aim of this study was to determine the presence of Tritrichomonas foetus in two dairy herds on the Altiplano Cundiboyacense. Twenty-one low-volume uterine lavages from cows with a history of reproductive problems in two dairy herds located in the municipality of Sibaté (Cundinamarca) and Ventaquemada (Boyacá) were evaluated. In the first herd, 10 cows were sampled and in the second, 11 cows, based on three inclusion criteria. The uterine lavages were obtained through infusion of physiological saline solution into the uterine body. The samples were centrifuged and seeded in Tritrichomonas basal medium for $10-15$ days at $37^{\circ} \mathrm{C}$. The protozoa were evaluated on the day of sampling and 10 and 15 days after incubation by means of direct viewing under a dark-field microscope. Positive samples were stained with Wright and Lugol to identify the morphological characteristics. This study showed that T. foetus was present in $61.8 \%$ of the animals sampled. The determination that $T$. foetus was present in $61.8 \%$ of the samples analyzed is a significant finding given that in the herds evaluated, this agent had not previously been diagnosed.
\end{abstract}

Keywords: Dairy cattle, Tritrichomonas foetus, culture, dark field microscopy.

\section{Resumo}

O objetivo do presente estudo, foi determinar a presença de Tritrichomonas foetus em dois rebanhos leiteiros no Altiplano Cundiboyacense. De vacas com um histórico de problemas reprodutivos, foram avaliados 21 lavados uterinos de pequeno volume, em dois rebanhos leiteiros localizados nos municípios de Sibaté (Cundinamarca) e Ventaquemada (Boyacá). No primeiro rebanho, 10 vacas foram amostradas e no segundo 11, baseado em três critérios de inclusão. Os lavados uterinos foram obtidos mediante infusão de solução salina fisiológica no corpo do útero. As amostras foram centrifugadas e semeadas em meio de cultura básico para Tritrichomonas por $10-15$ dias a $37^{\circ} \mathrm{C}$. Os protozoários foram avaliados no dia da colheita de amostras e 10 e 15 dias após incubação por meio de visualização direta sob um microscópio de campo escuro. As amostras positivas foram coradas com Wright e Lugol para identificar as características morfológicas. Este estudo mostrou que T. foetus estava presente em $61,8 \%$ dos animais amostrados. A determinaçáo de que $T$. foetus estava presente em $61,8 \%$ das amostras analisadas é um achado significativo, dado que nos rebanhos avaliados, esse agente não tinha sido previamente diagnosticado.

Palavras-chave: Rebanho leiteiro, Tritrichomonas foetus; cultivo, microscópio de campo escuro.

\footnotetext{
${ }^{*}$ Corresponding author: Rubiela Castañeda Salazar 


\section{Introduction}

Trichomonas foetus or Tritrichomonas foetus is the causal agent of bovine trichomoniasis or Tritrichomonas bovine abortion (QUIROZ, 1994). It is a flagellate protozoon with a piriform shape measuring 8-18 × 4-9 $\mu \mathrm{m}$; it has four flagella (FELLEISEN, 1999) and, under normal conditions at $37^{\circ} \mathrm{C}$, it is very motile (QUIROZ, 1994); its reproduction occurs by means of longitudinal binary fission (RIBEIRO et al., 2002).

$T$. foetus is sexually transmitted to a susceptible heifer or cow by an infected bull during mating. The bulls are the main reservoir for $T$. foetus, since they are long-standing shedders and play a major role in its dissemination (YULE et al., 1989; FELLEISEN, 1999; CAMPERO et al., 2003). However, T. foetus can also be transmitted through artificial insemination, given the capacity of the protozoon to remain viable in frozen semen that has been contaminated with preputial fluid during collection (CAMPERO; COBO, 2006; STOLTENOW; DYER, 2007; RAE; CREWS, 2006).

The life cycle of Tritrichomonas spp is direct and there is no intermediary host (OTTE et al., 2005; CAMPERO et al., 2003. Its definitive host is cattle (Bos taurus and Bos indicus), and it colonizes their genital tract in an ascending manner without causing invasion. It becomes established on mucosal surfaces, in secretions and in the glandular lumen of the sexual organs of both bulls and cows (SINGH et al., 2004; BENCHIMOL et al., 2006).

Bovine trichomoniasis is characterized by transitory female infertility. All sexually mature females are susceptible. The main clinical manifestations are abortion, heat repetition, decreased pregnancy ratio, endometritis, metritis, pyometra and, in some cases, fetal maceration (ROSSANIGO, 1998; FELLEISEN, 1999; JEMILOHUN et al., 2005).

T. foetus in females is diagnosed through detecting the protozoon in uterine lavage samples or vaginal swabs, using dark-field microscopy (KASIMANICKAM et al., 2005; McMILLEN; LEW, 2006) and/or post-centrifugation sediment staining with the Wright stain. Along with detection, it is possible to evaluate the inflammatory response and the presence of uterine desquamated epithelial cells (UDECs) (SALCEDO, 2004).

Bovine trichomoniasis is a disease with worldwide distribution that is of great importance in countries that have high cattle production. Its importance is based on the major economic losses due to reproductive problems and the difficulties involved in eradicating it from herds. Given that this disease is on the list of diseases reported by the OIE (World Organization for Animal Health) as an epidemiologically important disease that has enzootic characteristics, it is very important to have epidemiological knowledge of its presence in cattle-producing areas, in order to evaluate herd health status and participate in preventive programs, since there is no effective curative treatment that eliminates this parasite (OIE, 2004).

The current situation concerning bovine trichomoniasis in Colombia is uncertain, given that the last reports, which were made by the Colombian Corporation for Agricultural Research (CORPICA), date from 1999. However, its presence is not unknown especially in very important cattle producing areas. Based on the above, this study had the aim of preliminarily evaluating two herds on the Altiplano Cundiboyacense to determine the health status concerning this pathogenic agent.

\section{Materials and Methods}

Study population and sampling: this study was conducted in two herds on the Altiplano Cundiboyacense. The first herd was located in the municipality of Sibaté, Cundinamarca (herd 1), with a herd population of 322 cows; and the second was located in Ventaquemada, Boyacá (herd 2) with 71 cows. It was known that the two dairy herds had similar reproductive, health and feeding management practices, which included artificial insemination programs and the use of a bull for repeated cow servicing along with the possibility of undesired mating due to pasture sharing, as seen in herd 2 . The inclusion criteria were: 1 . nonpregnant cows; 2 . no antimicrobial treatment for 15 days before sampling; 3. cows with a history of reproductive problems such as metritis, low fertility, heat repetitions or abortions. These inclusion criteria made it possible to obtain a sample of $3 \%(n=10)$ of the animals in herd 1 and $15.4 \%(n=11)$ in the second herd.

Sampling and sample transportation: The uterine lavage samples were obtained by infusing 40 to $50 \mathrm{~mL}$ of sterile saline solution into the uterine horn using a syringe connected to a uterine tube or to a $18 \mathrm{Fr}^{\circ}$ Foley catheter. The uterine horn was massaged and retracted to collect the fluid by means of aspiration (ROSSANIGO, 1998); the sample was transferred to a $50 \mathrm{~mL}$ conical tube and it was labeled with the animal's identification number and the name of the herd. All the samples were transported to the laboratory for evaluation within six hours at room temperature, to ensure the viability of $T$. foetus.

Macroscopic sample evaluation: The samples were macroscopically evaluated for appearance, color and presence of sediment.

Cytological evaluation: All the uterine lavage samples were centrifuged at 500-100 rpm for five minutes to avoid cell lysis. An aliquot of $100 \mu \mathrm{L}$ of sediment was taken for direct determination of the presence $T$. foetus using dark-field microscopy. A further $100 \mu \mathrm{L}$ was used to make smears that were stained using Wright staining, to observe the morphological features of the protozoon, especially the wavy membrane and flagella. The presence of any inflammatory response mediated by polymorphonuclear leukocytes (PMNLs), mononuclear cells and UDECs was also evaluated. UDECs were assessed using the nucleus-cytoplasm ratio, nucleus position and characteristics, cytoplasm appearance and cell shape.

T. foetus cultures: $2 \mathrm{~mL}$ from the previously obtained sediment were transferred to conical tubes containing $10 \mathrm{~mL}$ of Tritrichomonas broth $(25 \mathrm{~g} / \mathrm{L}$ of hydrolyzed liver, $5 \mathrm{~g} / \mathrm{L}$ of $\mathrm{D}(+)$ glucose, $6.5 \mathrm{~g} / \mathrm{L}$ of $\mathrm{NaCl}, 0.8 \mathrm{~g} / \mathrm{L}$ of agar, $80 \mathrm{~mL} / \mathrm{L}$ of equine serum and $375 \mathrm{mg} / \mathrm{L}$ of chloramphenicol). These were incubated for 8 and 15 days at $37^{\circ} \mathrm{C}$ and, after that, the cultures were evaluated using dark-field microscopy and Lugol and Wright staining (ROSSANIGO, 1998; LEVI et al., 1997; LUN; GAJADHAR; 1999).

Statistical analysis: Statistical association analysis was performed using the chi-square $\left(\chi^{2}\right)$ test with a p value $<0.05$ to determine the probable associations between the morphological characteristics 
of the sediment and the presence of $T$. foetus and between the cytological findings and $T$. foetus. These analyses were done using the $\mathrm{R}$ statistical software under a freeware license.

\section{Results}

All the 21 uterine lavages showed different gross appearances. Five samples $(23.81 \%)$ had a normal translucent appearance without sediment; eight samples were turbid (38.1\%); two samples $(9.52 \%)$ were bloody; another two were mucupurulent (9.52\%); and four samples were bloody and mucupurulent (19.04\%). The statistical analysis did not show any association between sample appearance and the presence of $T$. foetus $(\mathrm{p}=0.360)$. In the five translucent samples without sediment, there was no evidence of UDECs or inflammatory response mediated by PMNLs or mononuclear cells, except in one sample, which showed occasional UDECs. Among the remainder of the samples (16) with abnormal appearance, four (25\%) contained UDECs, three (18.75\%) had PMNLs and four (25\%) had a combination of UDECs and PMNLs. The last five samples did not show any evidence of UDECs or PMNLs. There was no evidence of mononuclear cells in any of the samples. The $\chi^{2}$ test indicated that there was no association between the cytological response and the presence of $T$. foetus in the samples $(\mathrm{p}=0.171)$.

The presence of $T$. foetus was determined using cultures and dark-field microscopy. This was done based on determination of the morphological characteristics of the protozoon, such as the anterior flagella, posterior flagellum and undulating membrane (Figure 1). It was found that $60 \%$ (6) of the uterine samples from cows in herd 1 were positive for the parasite. In herd 2, 63.6\% (7) of the samples were also positive, as seen in Figure 2. The average proportion of positive animals was $61.8 \%$.
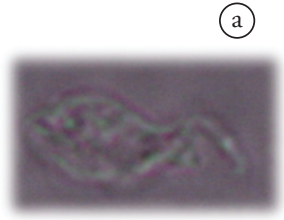

Figure 1. Tritrichomonas foetus morphology observed in the positive samples in the study. a: Fresh Lugol staining and dark-field microscopy $40 \times$; b-c: Wright staining $100 \times$.

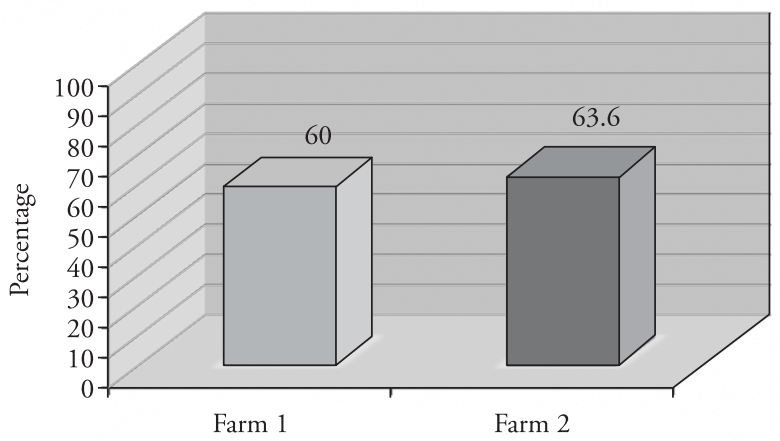

Figure 2. Presence of Tritrichomonas foetus in two herds located in the municipality of Sibaté and Ventaquemada, Colombia.
The presence of $T$. foetus was determined using dark-field microscopy on the sampling day and on the $8^{\text {th }}$ and $15^{\text {th }}$ days after culturing. In herd 1, all the samples were negative when examined on the sampling day, but there were four positive samples on the $8^{\text {th }}$ day and two on the $15^{\text {th }}$ day after culturing. In the case of herd 2 , three samples were found to be positive on the sampling day and four after culturing.

\section{Discussion}

Although the average proportion of positive cases of $T$. foetus $(61.8 \%)$ found in our study is higher than what has been reported previously, it is in partial agreement with the report made by CORPICA from a study on vaginal and uterine secretions in 1999, which was the last report published in Colombia before the present study. The CORPICA study determined the etiological agents of abortion and infertility among cattle in the department of Nariño and the upper Putumayo region and reported prevalences of $16.7 \%$ in 115 herds in Nariño and $48.3 \%$ in the upper Putumayo. In that study, $T$. foetus was considered to be the second most important etiological agent of reproductive problems in cattle (GONZÁLEZ; PATIÑO, 1999).

Given that most of the prevalence reports on T. foetus are based mainly on evaluation of preputial scrapings and lavages and not on uterine lavage, this means that the reported data both in Colombia and in any other cattle-raising country are mostly based on studies on the male population. Griffiths et al. (1982)evaluated eight dairy-producing areas of Colombia within the Andean, Caribbean and Orinoco regions and showed that $18.4 \%$ of the bulls in those regions were positive for T. foetus (GRIFFITHS et al., 1982). This number seemed to have decreased two year later when an evaluation of bulls in 103 farms in eight dairy regions of Colombia was again performed, and the prevalence was then determined to be $13.7 \%$ (GRIFFITHS et al., 1984). After these studies, one pilot study done on some herds in the department of Meta, Colombia, in 1992, demonstrated that the main causal agents of abortion in cattle were Brucella abortus, Chlamydia psittaci, five serovars of Leptospira interrogans and infectious rhinotracheitis virus (IBRV), which have been the main pathogens investigated in females. Evaluations on T. foetus, Campylobacter foetus and Haemophilus somnus were left to be done in males (PARKER et al., 1999). Other than these studies dating from ten years ago, no new study or evidence has been reported by the Colombian Institute for Agriculture (ICA) over recent years regarding the current situation of bovine trichomoniasis (ICA, 2008).

The prevalence of $T$. foetus among males has been determined in different countries such as Australia, with a prevalence of $65.6 \%$, Spain 37\%, USA 30.4\% and Argentina 28\% (MENDOZAIBARRA et al., 2012). Another study conducted in Spain showed a prevalence of $3.6 \%$ in males, and these bulls accounted for $68.6 \%$ of the total population of bulls in 350 herds in which both direct mating and artificial insemination were used. These data made it possible to calculate that $42.5 \%$ of the cows in these herds could be exposed to an infected bull (MARTÍN-GÓMEZ et al., 1998). The prevalence of $T$. foetus reported in the eastern states of the USA was between 4 and 7\%; however, in studies carried out 
in Alabama, where 374 bulls were tested, only one animal was positive, thus resulting in $0.27 \%$ prevalence. This was confirmed by using molecular tests such as PCR (RODNING et al., 2007). In Florida, the reported prevalence of the protozoon was $6 \%$ in individual bulls and $30.4 \%$ in the herd, as a result of the direct mating with bulls that was used on these farms (RAE et al., 2004). Studies conducted in Argentina indicated that the prevalence of T. foetus was $2.7 \%$ among 542 sampled bulls belonging to 44 herds (ROSSANIGO, 1998). On the other hand, in a study designed to examine the self-limiting nature of the disease, using uterine lavage sampling, prevalences of $3.9 \%$ and $3.1 \%$ were determined among nonpregnant and pregnant cows respectively, thus showing a low prevalence after 90 days of sexual rest (MANCEBO et al., 1995). The herd diagnosis is usually made by evaluating the bulls and the definitive diagnosis is made by observing $T$. foetus in the samples collected through either preputial scraping or lavage (STOLTENOW; DYER, 2007). Therefore, the data on asymptomatic carriers, persistence of infection in the herds and the possibility of spontaneous sexual contact have mainly come from bulls, given that the recommended samples for diagnosis are preputial lavages (OIE, 2004). It has been reported that the gold standard for diagnosing T. foetus consists of culturing the live microorganism from smegma or cervicouterine mucus. However, in studies in which samples from the vaginal mucosa or from uterine lavage were used, these were not used to make a diagnosis but to evaluate adhesion to the vaginal mucosa or determine the colonization of parts of the reproductive tract such as the oviduct (CORBEIL et al., 1989; GRAHN et al., 2005; BENCHIMOL et al., 2006). Nonetheless, the results from our study and from studies conducted in Argentina suggest that uterine lavage is an excellent diagnostic technique for determining the presence of T. foetus in herds in which artificial insemination is used, such as herd 1 , or in which there is shared pasturage, with possible direct mating, as in herd 2.

These data on asymptomatic carriers, along with the persistence of infection in the herds, suggest that cows' exposure to this agent is greater, given that the presence of at least one bull infected with T. foetus leads to a fourfold increase in the chances of having trichomoniasis in the herd (MARDONES et al., 2008).

Statistical testing for associations between the cytological characteristics of the samples and the presence of $T$. foetus did not show any association. This was probably because there was no inflammatory response in the samples that were positive for the protozoon. The lack of inflammatory response results from the parasite's lack of invasiveness and the fact that it becomes attached to the mucosa of the reproductive tract without triggering any inflammatory response, thereby maintaining the structural integrity of the vaginal mucosal membrane in nonpregnant cows (DA ROCHA-AZEVEDO et al., 2005; SINGH et al., 2004). The presence of UDECs in five of the thirteen samples can be considered to be due to the timing of the estrous cycle and this was unrelated to the presence of $T$. foetus.

Since in both herds the cows are served mainly using artificial insemination, it is important that the semen used should be tested for the presence of $T$. foetus. This is because, as mentioned previously, the parasite can survive in frozen semen if this is contaminated with preputial fluid during semen collection. Moreover, the practice of alternating direct mating in herd 2 implies higher risk relating to the bulls because of the presence of asymptomatic carriers. This makes it essential to also test the bulls.

The high prevalence of $T$. foetus found in the samples suggests that sanitary management is an issue to be addressed in relation to these herds, with the aim of decreasing or eliminating the spread of the infection among the bulls and cows in the herds.

\section{Conclusions}

Determination of T. foetus in $21(61.8 \%)$ of the uterine lavage samples, using dark-field microscopy and culturing, is an important finding for these two herds and also shows that the cows are an important source of infection in herds.

Direct evaluation of fresh samples using dark-field microscopy does not have the sensitivity that can be obtained from culturing. This is probably due to the low parasite concentration in these low-volume uterine samples. Therefore, the combination of uterine lavage sampling and culturing improves the sensitivity of the diagnostic technique.

\section{Acknowledgements}

To the farm owners, to Dr. Olimpo Oliver E. at the large animal clinic of FMVZ-UN, Colombia for his collaboration, and to the students and teaching assistants of the reproduction clinic of FMVZ-UN for all the help provided during this study.

\section{References}

Benchimol M, Dias AB, Fontes R. Interaction of Tritrichomonas foetus and the bovine oviduct in an organ culture model. Vet Parasitol 2006; 140(3-4): 244-250. http://dx.doi.org/10.1016/j. vetpar.2006.04.011

Campero C, Cobo E. Tritrichomonas foetus: patogénesis de la mortalidad embrionaria/fetal, caracterización de antígenos vacúnales y respuesta inmune inducida. Rev Med Vet, Bs As Argentina 2006; 87: 47-56.

Campero CM, Rodriguez DC, Bolondi A, Cacciato C, Cobo E, Perez S, et al. Two-step (culture and PCR) diagnostic approach for differentiation of non-T. foetus trichomonads from genitalia of virgin beef bulls in Argentina. Vet Parasitol 2003; 112(3): 167-175. http://dx.doi. org/10.1016/S0304-4017(02)00423-5

Corbeil L, Hodgson JL, Jones DW, Corbeil RR, Widders PR, Stephens LR. Adherence of Tritrichomonas foetus to Bovine Vaginal Epithelial Cells. Infect Immun 1989; 57(7): 2158-2165.

Da Rocha-Azevedo B, De Melo-Braga M, Silva-Filho FC. Intrastrain clonal phenotypic variation of Tritrichomonas foetus is related to the cytotoxicity exerted by the parasite to cultured cells. Parasitol Res 2005; 95(2): 106-112. http://dx.doi.org/10.1007/s00436-0041251-0

Felleisen RSJ. Host-parasite interaction in bovine infection with Tritrichomonas foetus. Microbes Infect 1999; 1(10): 807-816. http://dx.doi. org/10.1016/S1286-4579(99)80083-5

González HGC, Patiño REB. Principales agentes infectocontagiosos del aborto e infertilidad en el ganado lechero de Nariño y alto Putumayo. 
Colombia: Ministerio de Agricultura y Desarrollo Rural; 1999. p. 22-24. Corporación Colombiana de Investigación Agropecuaria Regional, no. 5. Programa Nacional de Transferencia de Tecnología PRONATTA. Available from: http://201.234.78.28:8080/jspui/ bitstream/123456789/201/1/20061127144049_Agentes\%20 aborto\%20infertilidad\%20ganado\%20lechero.pdf.

Grahn RA, Bondurant RH, Van Hoosear KA, Walker RL, Lyons LA. An improved molecular assay for Tritrichomonas foetus. Vet Parasitol 2005; 127(1): 33-41. http://dx.doi.org/10.1016/j. vetpar.2004.08.018

Griffiths IB, Gallego MI, Villamil LC. Factores de infertilidad y pérdidas económicas en ganado de leche en Colombia. Santa fe de Bogotá: ICA; 1982.

Griffiths IB, Gallego MI, De Leon LS. Levels of some reproductive diseases in the dairy cattle of Colombia. Trop Anim Health Prod 1984; 16(4): 219-223. http://dx.doi.org/10.1007/BF02265325

Instituto Colombiano Agropecuario - ICA. Boletines Epidemiológicos anuales. ICA; 2008. [cited 2011 May 26]. Available from: http:// www.ica.gov.co/getattachment/e205da92-1991-4de4-b412-

29d6dae2ae40/2008-(1).aspx.

Jemilohun PF, Garnett T, Burgess DE. Isolation, Partial Purification, and Immunogenicity of Flagella from Tritrichomonas foetus. J Eukaryot Microbiol 2005; 52(3): 245-249. http://dx.doi.org/10.1111/j.15507408.2005.00033.x

Kasimanickam R, Duffield TF, Foster RA, Gartley CJ, Leslie KE, Walton JS, et al. A comparison of the cytobrush and uterine lavage techniques to evaluate endometrial cytology in clinically normal postpartum dairy cows. Can Vet J 2005; 46(3): 255-259.

Levi MH, Torres J, Piña C, Klein RS. Comparison of the InPouch TV Culture System and Diamond's Modified Medium for Detection of Tritrichomonas vaginalis. J Clin Microbiol 1997; 35(12): 3308-3310.

Lun ZR, . Gajadhar AA. A simple and rapid method for staining Tritrichomonas foetus and Tritrichomonas vaginalis. J Vet Diagn Invest 1999; 11(5): 471-474. http://dx.doi. org/10.1177/104063879901100516

Mancebo OA, Russo AM, Carabajal LL, Monzon CM. Persistence of Trichomonas foetus in naturally infected cows and heifers in Argentina. Vet Parasitol 1995; 59(1): 7-11. http://dx.doi.org/10.1016/03044017(94)00734-T

Mardones FO, Perez AM, Martínez A, Carpenter TE. Risk factors associated with Tritrichomonas foetus infection in beef herds in the Province of Buenos Aires, Argentina. Vet Parasitol 2008; 153(3-4): 231-237. http:// dx.doi.org/10.1016/j.vetpar.2008.01.038

Martín-Gómez S, González-Paniello R, Pereira-Bueno J, Ortega-Mora LM. Prevalence of Tritrichomonas foetus infection in beef bulls in northwestern Spain. Vet Parasitol 1998; 75(2-3): 265-268. http://dx.doi. org/10.1016/S0304-4017(97)00189-1

McMillen L, Lew A. Improved detection of Tritrichomonas foetus in bovine diagnostic specimens using a novel probe-based real time PCR assay. Vet Parasitol 2006; 141(3-4): 204-215. http://dx.doi.org/10.1016/j. vetpar.2006.06.012
Mendoza-Ibarra JA, Pedraza-Díaz S, García-Peña FJ, Rojo-Montejo S, Ruiz-Santa-Quiteria JA, San Miguel-Ibáñez E, et al. High prevalence of Tritrichomonas foetus infection in Asturiana de la Montaña beef cattle kept in extensive conditions in Northern Spain. Vet J2012; 193(1): 146-151. http://dx.doi.org/10.1016/j.tvjl.2011.09.020

Organización Mundial de Sanidad Animal - OIE. Manual de la OIE Sobre Animales Terrestres. OIE; 2004. cap. 2.3.6. - Tricomoniasis. [cited 2009 Oct. 4]. Available from: http://web.oie.int/esp/normes/mmanual/ pdf_es/2.3.06_Tricomonosis.pdf.

Otte MJ, Ravenborg T, Hüttner K. A pilot study of elevated abortion and stillbirth ratios in cattle in the foothills of the Eastern plains of Colombia. Prev Vet Med 2005; 22(1-2): 103-113. http://dx.doi.org/10.1016/01675877(94)00394-X

Parker S, Campbell J, Ribble C, Gajadhar A. Comparison of two sampling tools for diagnosis of Tritrichomonas foetus in bulls and clinical interpretation of culture results. J Am Vet Med Assoc 1999; 215(2): 231-235.

Quiroz H. Parasitología y enfermedades parasitarias de animales domésticos. México: Limusa; 1994.

Rae DO, Crews JE. Tritrichomonas foetus. Vet Clin North Am Food Anim Pract 2006; 22(3): 595-611. http://dx.doi.org/10.1016/j. cvfa.2006.07.001

Rae DO, Crews JE, Greiner EC, Donovan GA. Epidemiology of Tritrichomonas foetus in beef bull populations in Florida. Theriogenology 2004; 61(4): 605-618. http://dx.doi.org/10.1016/ S0093-691X(03)00236-X

Ribeiro KC, Mariante RM, Coutinho LL, Benchimol M. Nucleus behavior during the closed mitosis of Tritrichomonas foetus. Biol Cell 2002; 94(4-5): 289-301. http://dx.doi.org/10.1016/S02484900(02)01206-6

Rodning SP, Wolfe DF, Carson RL, Wright JC, Stockdale HD, Pacoli $\mathrm{ME}$, et al. Prevalence of Tritrichomonas foetus in several subpopulations of Alabama beef bulls. Theriogenology 2007; 69(2): 212- 217. http:// dx.doi.org/10.1016/j.theriogenology.2007.09.014

Rossanigo C. Las enfermedades venéreas en los rodeos de cría; prevalencia, diagnóstico y control. Oeste Ganad. 1998;1(2): 22-24. [cited 2009 Oct. 24]. Available from: http://www.infogranjas.com.ar/ganaderia-ypesca/340-mayor-bovinos-leche/3341-las-enfermedades-venereas-enlos-rodeos-de-cria-prevalencia-diagnostico-y-control.

Salcedo P. Coloraciones tiles para facilitar la identificación de Tritrichomonas vaginalis en los laboratorios clínicos [Tesis]. Bogotá: Universidad de los Andes; 2004.

Singh BN, Lucas JJ, Hayes GR, Kumar I, Beach DH, Frajblat M, et al. Tritrichomonas foetus Induces Apoptotic Cell Death in Bovine Vaginal Epithelial Cells. Infect Immun 2004; 72(7): 4151-4158. http://dx.doi. org/10.1128/IAI.72.7.4151-4158.2004

Stoltenow CL, Dyer NW. Bovine Trichomoniasis a venereal disease of cattle. 2007. [cited 2011 Jun. 11]. Available from: http://thecattlesite. com/articles/1251/bovine-trichomoniasis-ia-venereal-disease-of-cattle-i.

Yule A, Skirrow SZ, Bondurant RH. Bovine Trichomoniasis. Parasitol Today 1989; 5(12): 373-377. http://dx.doi.org/10.1016/01694758(89)90298-6 